\title{
Nitrogen Balance During Sweet Sorghum Cropping Cycle as Affected by Irrigation and Fertilization Rate
}

\author{
Stella Lovelli, Massimo Monteleone ${ }^{1}$, Gerardina Posca, Michele Perniola \\ Dipartimento di Scienze dei Sistemi Colturali, Forestali e dell'Ambiente, Università della Basilicata \\ Viale dell'Ateneo Lucano 10, 85100 Potenza, Italy \\ ${ }^{1}$ Dipartimento di Scienze Agro-Ambientali, Chimica e Difesa Vegetale, Univeristà di Foggia \\ Via Napoli 25, 71100 Foggia, Italy
}

Received: 23 June 2008. Accepted: 20 October 2008.

\begin{abstract}
A two-year trial was carried out on sweet sorghum, grown in semi-arid environments of southern Europe. The trial was aimed to monitor the main components of the crop N-balance under different irrigation regimes and nitrogen fertilization rates, in factorial combination. A rainfed condition (only one watering soon after sowing) was compared with a deficit irrigation regime and a full irrigation treatment (50 and $100 \%$ restoration of total crop water consumption, respectively) in a similar way, an unfertilized control was tested with respect to $\mathrm{N}$ application rates of 60 and $120 \mathrm{~kg} \mathrm{ha}^{-1}$, respectively. Crop nitrogen uptake always showed to be the highest N-balance components and was included in the range of 125-194 kg ha-1 during 1997-1998, with respect to the total shoot biomass, according to the nitrogen fertilization rate; consequently, it significantly reduced both nitrogen concentration in the soil solution and the total nitrogen loss due to drainage. Nitrogen concentration in the drainage water didn't result to be strictly dependent on the rate of fertilizer applied but on the actual soil nitrogen content; the maximum registered value of total nitrogen lost by leaching was $1.9 \mathrm{~kg} \mathrm{ha}^{-1}$. Differently, total nitrogen loss due to volatilisation was proportional to the amount of fertilizer applied; irrigation favourably reduced this kind of loss. The limited amount of $\mathrm{N}$-volatilisation loss was probably due to the neutral $\mathrm{pH}$ soil conditions; as an order of magnitude, referring to the highest fertilized but rainfed treatment, the utmost $\mathrm{N}$-volatilisation loss was equal to $5.5 \mathrm{Kg} \mathrm{ha}^{-1}$, as an average over the three years, that is to say less than the $5 \%$ of the fertilization rate. A fertilisation rate of 120 $\mathrm{Kg} \mathrm{ha}^{-1}$ of nitrogen, together with water application, generally produced a balance between crop $\mathrm{N}$-uptake and total N-loss due to volatilisation and drainage (only the stalk biomass was considered in this calculation). Lower rates of fertilizing nitrogen, indeed, determined a depletion in the soil nitrogen content because of the high crop biomass and the strong $\mathrm{N}$-uptake by the crop, while rainfed conditions at the highest fertilization rate generally established a N-surplus.
\end{abstract}

Key-words: crop N-uptake, N-fertilizer loss, nitrogen use efficiency, Sorghum bicolor.

\section{Introduction}

Sweet sorghum (Sorghum bicolor L. Moench) for biomass and ethanol production was recently fostered by the European agricultural policy to promote non-food crops. In fact, sweet sorghum is a potential source of ethanol, which can be directly used in a mixture with gasoline, or react with isobutylene to form ethyl tert-butyl ether (ETBE), an octane additive for gasoline (Barbanti et al., 2006). The climatic conditions of southern Europe are well suited to this crop
(Mastrorilli et al., 1995). Previous studies carried out in southern Italy highlight the good production potentials of this species though they strictly depend on irrigation practices (Perniola et al., 1992). As a matter of fact, in semi-arid environments, the summer growing season has to rely upon irrigation to get adequate yield response (De Franchi et al., 1994).

The interaction between irrigation regime and nitrogen application rates is a crucial aspect of the cropping technique, in order to obtain the

\footnotetext{
* Corresponding Author: Tel.: +39 0971 205384; Fax: +39 0971 205378. E-mail address: stella.lovelli@unibas.it. The Authors equally share the work.
} 
most convenient yield as well as an efficient use of nitrogen and water applied together with the minimum risk of environmental impact due to $\mathrm{N}$ leaching or volatilisation (Perniola et al., 1999). A fast growing, high biomass crop, such as sweet sorghum, is able to considerably influence both water and nitrogen balance in proportion to its sink activity, exploiting soil reserves, and the set of agrotechnical inputs applied.

A proper way to account for the use and fate of nitrogen in the soil-plant-atmosphere continuum is to solve the N-balance; this "book-keeping" criterion allows to optimise the fertilisation technique and to achieve a sustainable use of the soil nutritional resources.

The limited amount of available information on such topics, particularly with respect to sweet sorghum grown in semi-arid environments of southern Europe, encouraged to plan and start this trial. The first purpose of the study was to monitor the main components of the nitrogen balance as applied to sweet sorghum under different irrigation regimes and nitrogen fertilisation rates. Some indexes on nitrogen use were derived from this balance; they proved to be useful to check the proper $\mathrm{N}$-fertilization rate and irrigation regime.

\section{Materials and methods}

\subsection{Description of the experimental areas}

The trial was carried out over a two-year period (1997-98) in southern Italy, at Gaudiano di Lavello (41 $03^{\prime}$ N, 15 42' E) in 1997 and 1998. Gaudiano is an inland area at the north of the Basilicata Region, about $300 \mathrm{~m}$ above the sea level. Table 1 reports the main soil characteristics of the experimental area.

\subsection{Description of the trial}

Sweet sorghum (cv. Keller) was sown on May (21 May, 1997; 21 May, 1998) with rows $50 \mathrm{~cm}$ apart and an average plant density of 11 plants $\mathrm{m}^{-2}$ at harvest. Before sowing, $150 \mathrm{Kg} \mathrm{ha}^{-1}$ of $\mathrm{P}_{2} \mathrm{O}_{5}$ and $100 \mathrm{Kg} \mathrm{ha}^{-1}$ of $\mathrm{K}_{2} \mathrm{O}$ were applied. Other cropping practices included hoeing for weed control and hand harvesting in late October.

Three irrigation regimes (irrigation only at sowing, $\mathrm{V}_{0}$, re-establishment of 50 and $100 \%$ of total water consumption during the whole growing cycle, $\mathrm{V}_{50}$ and $\mathrm{V}_{100}$ ) were factorially combined with three nitrogen fertiliser rates (un-fertilised control, $\mathrm{N}_{0}$, application of 60 and $120 \mathrm{Kg}$ $\mathrm{ha}^{-1}$ of nitrogen as ammonium sulphate, 1/3 of which at pre-sowing and $2 / 3$ at the beginning of stem elongation, $\mathrm{N}_{60}$ and $\mathrm{N}_{120}$ ).

The unconstrained crop water consumptions (ETc) were continuously detected through two $2 \times 2 \mathrm{~m}$ mechanical weighing lysimeters located in the middle of the plots $\mathrm{V}_{100} \mathrm{~N}_{0}$ and $\mathrm{V}_{100} \mathrm{~N}_{120}$. The irrigation frequency was determined by keeping the allowable soil water depletion constant (equal to $30 \mathrm{~mm}$ until full ground canopy cover and to $50 \mathrm{~mm}$ later on) and by correspondently changing the watering time intervals. The crop was drip-irrigated with driplines $1 \mathrm{~m}$ apart and on-line drippers of $2 \mathrm{l} \mathrm{h}^{-1}$ at $30 \mathrm{~cm}$ spacing.

\subsection{Data acquisition and processing}

The crop water balance:

$$
\pm \Delta \theta=R+I r-E T-R o-D r
$$

was solved measuring or estimating the following components: the rains $(R)$ were daily detected at the agro-meteorological stations; the exact watering volumes (Ir) were measured through volumetric valves at the head of each experimental plot; runoff losses (Ro) were considered to be zero, the land being flat and the rain intensity never exceeding the soil infiltration rate; drainage water $(D r)$ was estimated as the difference between inflow $(R+I r)$ and the soil water storage capacity for $90 \mathrm{~cm}$ depth at each irrigation time or rain event, considering the soil water amount before the event. As regard the $\mathrm{V}_{100} \mathrm{~N}_{0}$ and $\mathrm{V}_{100} \mathrm{~N}_{120}$ treatments, the ETc

Table 1. Main soil characteristics at the experimental station.

\begin{tabular}{|c|c|c|c|c|c|c|c|c|c|c|c|}
\hline Locality & $(\%)$ & Loam & $(\%)$ & $\begin{array}{c}\text { Organic } \\
\text { matter } \\
(\%)\end{array}$ & $\begin{array}{c}\text { Total } \\
\text { Nitrogen } \\
(\mathrm{g} / \mathrm{Kg})\end{array}$ & $\begin{array}{l}\mathrm{P}_{2} \mathrm{O}_{5} \\
(\mathrm{ppm}) \\
\end{array}$ & $\begin{array}{c}\mathrm{K}_{2} \mathrm{O} \\
(\mathrm{ppm}) \\
\end{array}$ & $\mathrm{pH}$ & $\begin{array}{c}\begin{array}{c}\text { Soil bulk } \\
\text { density }\end{array} \\
\left(\mathrm{Kg} / \mathrm{dm}^{3}\right)\end{array}$ & $\begin{array}{c}\text { Field } \\
\text { Capacity } \\
-0.3 \text { bar } \\
(\% \text { d.w. })\end{array}$ & $\begin{array}{c}\text { Wilting } \\
\text { Point } \\
-15 \text { bar } \\
\text { (\% d.w.) } \\
\end{array}$ \\
\hline Gaudiano & 49.7 & 28.3 & 22.0 & 1.58 & 0.97 & 88.2 & 210 & 7.1 & 1.25 & 30.4 & 16.0 \\
\hline
\end{tabular}


component of the water balance (as well as $D r$ ) was directly measured through the lysimeters; as for the other treatments, the actual $E T$ was estimated by measuring the change in gravimetric moisture in the soil volume explored by roots $( \pm$ $\Delta \theta)$ between each single irrigation event.

The nitrogen balance (Florenzano, 1986):

$$
\pm \Delta S R=F+I W+R-C U-V-L
$$

was set up through measuring or estimating the following components: variations in the soil nitrogen reserve $( \pm \Delta S R)$; nitrogen fertilizer application $(F)$; nitrogen content of irrigation water $(I W)$ and rainfall $(R)$; crop uptake $(C U)$; Nvolatilisation $(V)$ and $\mathrm{N}$-leaching $(L)$ losses. To calculate $I W, R$ and $L$, the concentrations of N$\mathrm{NO}_{3}, \mathrm{~N}-\mathrm{NO}_{2}$ and $\mathrm{N}-\mathrm{NH}_{4}$ in water samples were colorimetrically determined and subsequently read through the spectrophotometer (mod. Hach Dr 2000); the total water inflow and outflow volumes were subsequently estimated according to the water balance approach. The concentration of other eventual nitrogen compounds dissolved in water was considered to be negligible (Dowdell et al., 1979).

Drainage water samples were taken directly from the lysimeters (with respect to the plots equipped with these devices) or from microlysimeters (soil solution extractor) installed at 30, 60 and $90 \mathrm{~cm}$ of depth (in the plots where lysimeters were not available). Soil depth in experimental areas is, in the average, $70 \mathrm{~cm}$, therefore root zone is localized in this soil profile, as a consequence $90 \mathrm{~cm}$ is sufficient for the computation of crop uptake and nitrogen leaching. Crop N-uptake was calculated by measuring the dry biomass of leaves, stalks and panicles and determining the corresponding Kjeldhal nitrogen content.

Volatilisation loss of $\mathrm{N}$-ammonium was detected by capturing ammonia through a static closed system installed at the soil surface and saturated with $\mathrm{H}_{3} \mathrm{PO}_{4}$ and glycerin. In the lab, a subsequent distillation and titration of the ammonium ion (Marshall and Debell, 1980) allowed the measurement of this component of the N-balance. Frequency of volatilisation measurement was every three days immediately after fertilization and subsequently was weekly, each measurement was the cumulated value of the previous period.

$\mathrm{N}$-denitrification $\left(\mathrm{N}_{2}, \mathrm{NO}\right.$ and $\left.\mathrm{N}_{2} \mathrm{O}\right)$ is generally considered to be negligible in agricultur- al systems (Smith et al., 1990), especially when anaerobiosis conditions do not occur, in fact according to our irrigation scheduling (the average irrigation interval was ten days, and with irrigation we restored only the field capacity), and considering rain regimes during the experiment and soil characteristics the denitrification should be really negligible, for this reason these kind of losses was not detected. In this work, the variations in the soil nitrogen reserve were calculated as residue of the N-balance.

The apparent nitrogen recovery

$$
A N R=\left(C U_{f}-C U_{0}\right) / F
$$

was also determined as the ratio of the increased nitrogen uptake by the fertilised crop $\left(C U_{f}\right)$ as compared with the unfertilised crop $\left(C U_{0}\right)$, over the fertilization rate (Varvel and Peterson, 1991). This indice assumes that the whole crop nitrogen uptake is derived from fertiliser.

The nitrogen agronomic efficiency

$$
N A E=\left(Y_{f}-Y_{N o}\right) / F
$$

was determined as the ratio of the fertilized crop production $\left(Y_{f}\right)$ as compared with the unfertilized crop production $\left(Y_{N o}\right)$ (kg of dry biomass) over the fertilization rate $(\mathrm{kg})$ (Giardini, 1989a).

The experimental treatments were arranged in the field according to a split-plot design with three replicates, the irrigation regimes in the plots and the nitrogen rates in the sub-plots. The percent data were submitted to the analysis of variance after angular transformation. The mean discrimination was performed according to the LSD test.

\section{Results}

\subsection{Climatic pattern and water balance during the two experiments}

Referring to the whole growing cycle (from May through October), the average temperature varied from a minimum of $21.6{ }^{\circ} \mathrm{C}$ in 1997 to a maximum of $23.8{ }^{\circ} \mathrm{C}$ in 1998 , being however close to the long term mean of $22.1{ }^{\circ} \mathrm{C}$; the radiative load was slightly higher in 1997 (with an average daily value of $265 \mathrm{~W} \mathrm{~m}^{-2}$ during two years). The overall precipitation recorded in each experimental year (Tab. 2) was approximately close to the long term mean of the same 
Table 2. Water balance for the three irrigation treatments in the two experimental years (all data are expressed in mm).

\begin{tabular}{|c|c|c|c|c|c|c|c|c|c|c|}
\hline \multirow[t]{2}{*}{$\begin{array}{l}\text { Irrig. } \\
\text { Treat. }\end{array}$} & \multicolumn{2}{|c|}{ Rain } & \multicolumn{2}{|c|}{ Irrigation } & \multicolumn{2}{|c|}{ Evapotranspiration } & \multicolumn{2}{|c|}{ Drainage } & \multicolumn{2}{|c|}{$\begin{array}{l}\text { Reduction in the } \\
\text { soil water reserve }\end{array}$} \\
\hline & 1997 & 1998 & 1997 & 1998 & 1997 & 1998 & 1997 & 1998 & 1997 & 1998 \\
\hline $\mathrm{V}_{100}$ & 161 & 182 & 527 & 696 & 607 & 896 & 111 & 0 & 30 & 18 \\
\hline $\mathrm{V}_{50}$ & 161 & 182 & 325 & 378 & 539 & 644 & 37 & 0 & 90 & 84 \\
\hline $\mathrm{V}_{0}$ & 161 & 182 & 124 & 80 & 370 & 372 & 0 & 0 & 85 & 110 \\
\hline
\end{tabular}

period $(191 \mathrm{~mm})$, with slightly lower values in $1997(161 \mathrm{~mm})$ with respect to the $1998(182 \mathrm{~mm})$. The seasonal irrigation volume (Tab. 2) supplied to fully satisfy crop water requirement $(\mathrm{ETc}=$ 607, $896 \mathrm{~mm}$ respectively in 1997, 1998), varied between $416 \mathrm{~mm}$ in 1997 and $696 \mathrm{~mm}$ in 1998 (Tab. 2); considering the long extent of the crop cycle and the great crop vegetative vigour, these high and uneven irrigation volumes are well representative of the irrigation requirements of this crop in southern Italy (Perniola et al., 1992).

In 1998, where rainfall events never exceeded $15 \mathrm{~mm}$, no drainage losses were measured from the lysimeter station located in treatments $\mathrm{V}_{100}$. Conversely, in 1997, corresponding to the days soon subsequent to rainfall events exceeding $20 \mathrm{~mm}$, a copious drainage was measured (in the lysimetric treatments $\mathrm{V}_{100}$ ) and estimated (in the other treatments). Over the whole growing period, the $\mathrm{V}_{100}$ drainage volumes totalled $111 \mathrm{~mm}$ in 1997 (Tab. 2). In 1997, the drainage volume dropped to $37 \mathrm{~mm}$ in the $\mathrm{V}_{50}$ treatment and became zero in $\mathrm{V}_{0}$ (Tab. 2).

\subsection{Nitrogen balance}

The nitrate concentration of the soil solution measured at Gaudiano in 1997 the average nitrate content in leaching waters varied from 17.5 $\mathrm{mg} \mathrm{l}^{-1}$ measured on 20 June 1997 to $4.5 \mathrm{mg} \mathrm{l}^{-1}$ on August 21, 1997. Therefore, at Gaudiano, nitrate concentration in drainage water never exceeded the allowable European threshold of 50 $\mathrm{mg} \mathrm{l}^{-1}$ for water potability (Dir. 91/676/CEE).

Considering the total nitrogen content in the drainage volumes of percolation waters (also including the form of nitrites and ammonia, generally only present as trace), the amount of total nitrogen lost by leaching was greater in the higher water regimes they varied from 0.6 to 1.9 $\mathrm{Kg} \mathrm{ha}{ }^{-1}$ of $\mathrm{N}$ respectively in the treatments $\mathrm{V}_{50} \mathrm{~N}_{60}$ and $\mathrm{V}_{100} \mathrm{~N}_{120}$. The effect of the fertiliser rate on nitrogen losses by leaching (Tab. 3) was always not significant.
Table 4 reports nitrogen cumulated losses by volatilisation in the form of ammonia at the end of the crop cycle. The statistical analysis has not shown any effect related to the year; whereas a decreasing fertilisation rate determined a significant reduction in nitrogen losses; in 1997 only, an increasing irrigation regime significantly reduced $\mathrm{N}$-volatilization. The effect of fertilisation was particularly evident in the days immediately after the fertilizer application (data not shown), due to the fact that nitrogen was sup-

Table 3. Nitrogen loss by leaching in 1997, all data are expressed in $\mathrm{kg} \mathrm{ha}^{-1}$.

\begin{tabular}{lccc}
\hline & \multicolumn{3}{c}{1997} \\
\cline { 2 - 4 } $\mathrm{N}$ fert. rate & $\mathrm{N}_{120}$ & $\mathrm{~N}_{60}$ & $\mathrm{~N}_{0}$ \\
Irrigation & 1.9 & 1.7 & 1.6 \\
\hline $\mathrm{V}_{100}$ & 0.7 & 0.6 & 0.6 \\
$\mathrm{~V}_{50}$ & - & - & - \\
$\mathrm{V}_{0}$ & F-test $^{\S}$ & LSD \\
\hline Irrigation & & $* *$ & 0.90 \\
$\mathrm{~N}$ fert. rate & & n.s. & \\
Irrig. x N fert. & & $* *$ & 0.11 \\
\hline
\end{tabular}

$\S * *$ highly significant $(\mathrm{P}<0.01)$; * significant $(\mathrm{P}<0.05)$; n.s. not significant.

Table 4. Nitrogen loss by ammonia volatilization in the three irrigation regimes and the three nitrogen fertilization rates during 1997 and 1998 sweet sorghum growing cycle. All data are expressed in $\mathrm{kg} \mathrm{ha}^{-1}$.

\begin{tabular}{lcccccc}
\hline $\mathrm{N}$ dose & \multicolumn{3}{c}{1997} & \multicolumn{3}{c}{1998} \\
\cline { 2 - 7 } Irrigation & $\mathrm{N}_{120}$ & $\mathrm{~N}_{60}$ & $\mathrm{~N}_{0}$ & $\mathrm{~N}_{120}$ & $\mathrm{~N}_{60}$ & $\mathrm{~N}_{0}$ \\
\hline $\mathrm{V}_{100}$ & 3.7 & 2.6 & 1.9 & 5.4 & 4.9 & 3.8 \\
$\mathrm{~V}_{50}$ & 3.4 & 3.2 & 2.2 & 5.1 & 4.6 & 3.5 \\
$\mathrm{~V}_{0}$ & 5.0 & 4.0 & 2.8 & 5.9 & 4.9 & 4.3 \\
\hline \multicolumn{3}{c}{ F-test $^{\S}$} & LSD & F-test & LSD \\
Irrigation & $*$ & 0.22 & n.s. & - \\
N fert. rate & $* *$ & 0.18 & ** & 0.41 \\
Irrig. x N fert. & n.s. & - & n.s. & -
\end{tabular}

$\S * *$ highly significant $(\mathrm{P}<0.01)$; * significant $(\mathrm{P}<0.05)$; n.s. not significant. 
Table 5. Crop nitrogen uptake as influenced by irrigation and nitrogen fertilization in the two experimental years; all data are expressed in $\mathrm{kg} \mathrm{ha}^{-1}$.

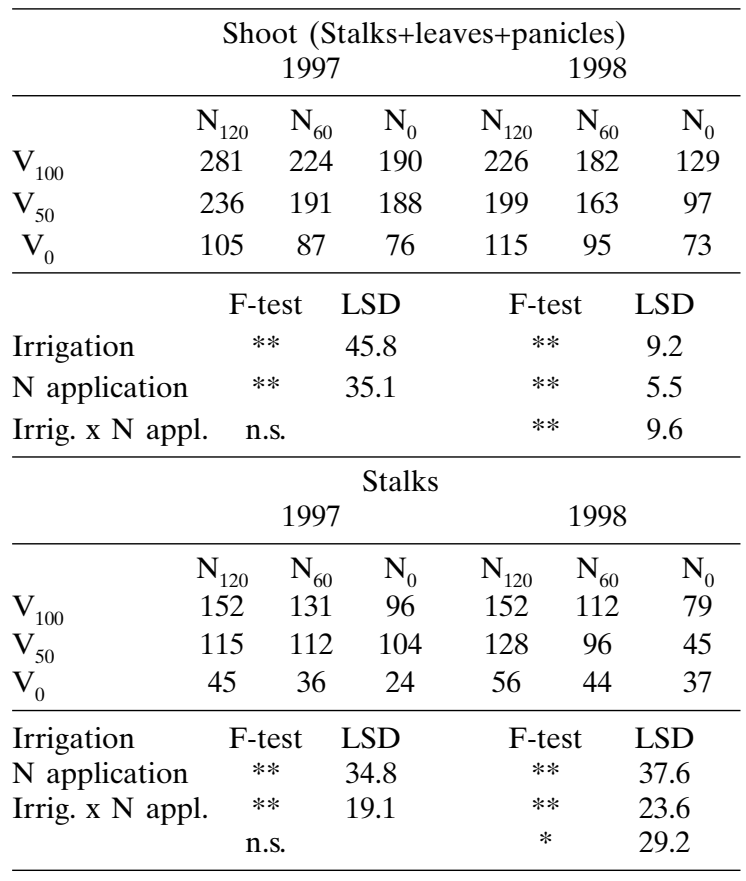

** highly significant $(\mathrm{P}<0.01)$; ${ }^{*}$ significant $(\mathrm{P}<0.05)$; n.s. not significant.

plied as ammonium sulphate (Giardini, 1989a).

Among the negative components of the nitrogen balance, crop N-uptake was significantly the highest (Tab. 5). In 1998, the irrigation regime significantly interacted with the nitrogen regime on the level of N-uptake. Crop N-uptake was lesser under conditions of limiting water supply and was not affected by the amount of fertiliser applied. Irrigation not only increased $\mathrm{N}$-uptake, as a consequence of the increased crop growth, but also made the fertilisation effect clear. Considering the highest irrigated treatments, averaging over the two years 199798, total above-ground crop nitrogen uptake increased from 159 to $253 \mathrm{Kg} \mathrm{ha}^{-1}$ and stalk uptake increased from 87 to $152 \mathrm{Kg} \mathrm{ha}^{-1}$ of N, moving from treatments $\mathrm{N}_{0}$ to $\mathrm{N}_{120}$, respectively. This occurred both as a result of the greater soil nitrogen availability and the greater amount of dry biomass produced, at harvest, in the more fertilised treatments; these latter, indeed, showed a higher efficiency in the assimilation processes (data not shown). It's worth to note that quite high amounts of nitrogen uptake were also recorded in the un-fertilised treatments
(Tab. 5). Considering the shoot N-uptake (leaves+stalks+panicles), averaged over the two years, 74 to $159 \mathrm{Kg} \mathrm{ha}^{-1}$ of $\mathrm{N}$ were removed from the soil moving from $\mathrm{V}_{0} \mathrm{~N}_{0}$ to $\mathrm{V}_{100} \mathrm{~N}_{0}$, respectively.

Nitrogen supply through rainfall and irrigation varied as a function of water inflow, the minimum value was of $5.6 \mathrm{Kg} \mathrm{ha}^{-1}$ measured in 1998 in the un-irrigated treatments to a maximum value of $38,97 \mathrm{Kg} \mathrm{ha}^{-1}$ of $\mathrm{N}$ in 1998 in the $\mathrm{V}_{100}$ treatments. The average nitrogen concentration was $1.0 \mathrm{mg} \mathrm{l}^{-1}$ in rainfall water, and 5.6 $\mathrm{mg} \mathrm{l}^{-1}$ in irrigation water derived from a surface reservoir.

Figure 1 summarizes the apparent nitrogen balance, obtained as the difference between nitrogen input and output, until the end of the growing cycle, measured over the two experimental years. Considering the total shoot N-uptake (stalks + leaves + panicles), a generalized reduction in soil nitrogen reserve is observed. In particular, the balance closed with a loss even when an application rate of $120 \mathrm{Kg} \mathrm{ha}^{-1} \mathrm{~N}$ was applied. Nitrogen deficit was particularly severe in the irrigated treatments where, as already mentioned, crop uptake played a significant role.

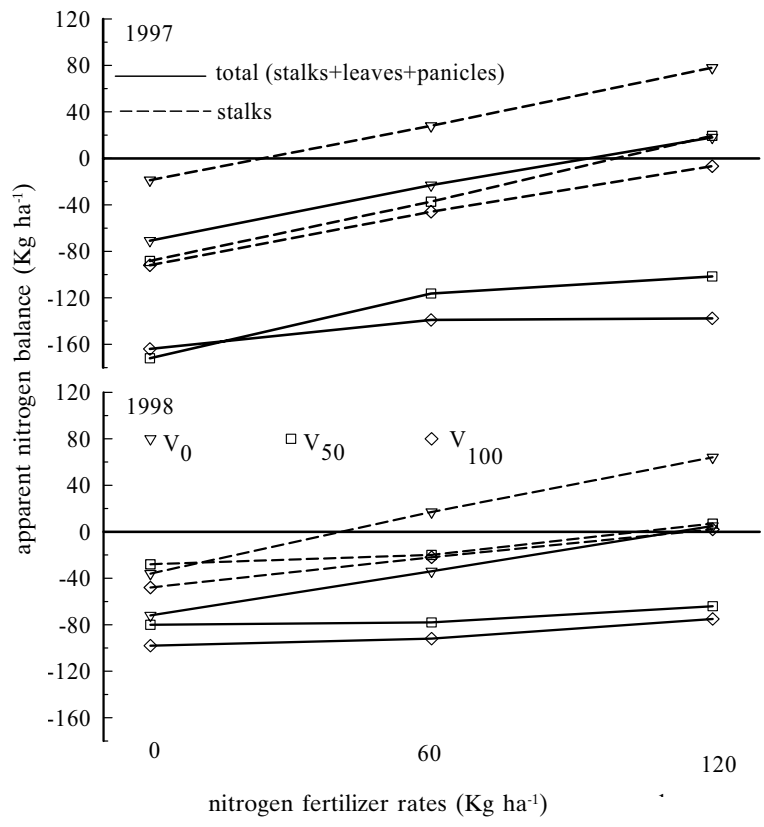

Figure 1. Apparent nitrogen balance at the end of the crop cycle as influenced by irrigation and nitrogen fertilization in the two experimental years. 


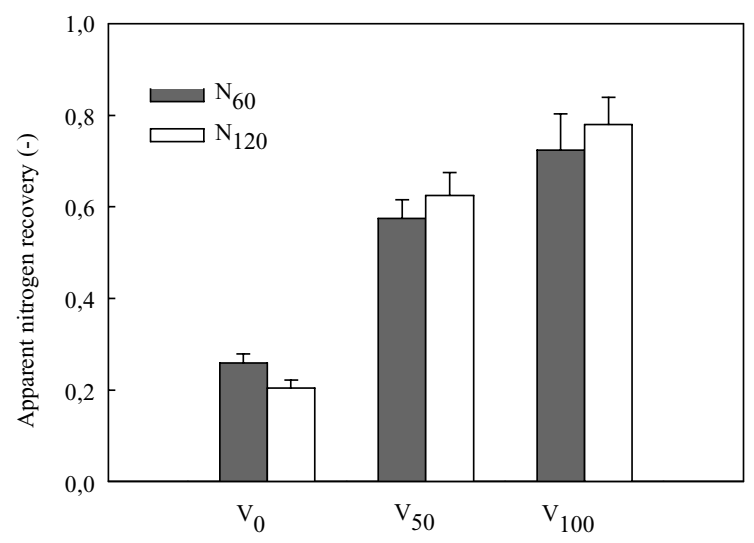

Figure 2. Apparent Nitrogen Recovery (A.N.R.) measured during 1997-98 on sweet sorghum subject to the irrigated $\left(\mathrm{V}_{0}, \mathrm{~V}_{50}, \mathrm{~V}_{100}\right)$ and fertilized $\left(\mathrm{N}_{60}, \mathrm{~N}_{120}\right)$ treatments. Vertical bars are standard error of the mean.

\subsection{Nitrogen agronomic efficiency}

Irrigation enhanced the Apparent Nitrogen Recovery (ANR) in better irrigated treatments (Fig. 2). Irrigation equally improved the nitrogen agronomic efficiency (NAE) (Fig. 3), highlighting a positive interaction between irrigation and fertilisation. The fertiliser rate being equal, the increase in yield with respect to the unfertilised control, for each unit of applied fertiliser, was gradually greater with increasing irrigation regime.

Differently from irrigation, fertilisation did not improved the above-said efficiency indexes (Figg. 2 and 3), except ANR that slightly increased in the fertilised treatments.

\section{Discussion}

During the two years of trial, the climatic pattern was hot and arid, as it is typically the case in the investigated area. The water balance over the two years is considered to be sufficiently representative of the investigated area. The full and regular re-establishment of evapotranspiration through irrigation, keeping the soil close to field capacity over most of the growing cycle, created the conditions for draining the amount of waters exceeding the soil storage capacity but this occurred only after abundant rainfall.

Nitrogen losses by leaching depend on the nutrient concentration in drainage water, mainly in the nitrate form, and on the corresponding drainage volumes. As previously reported, in

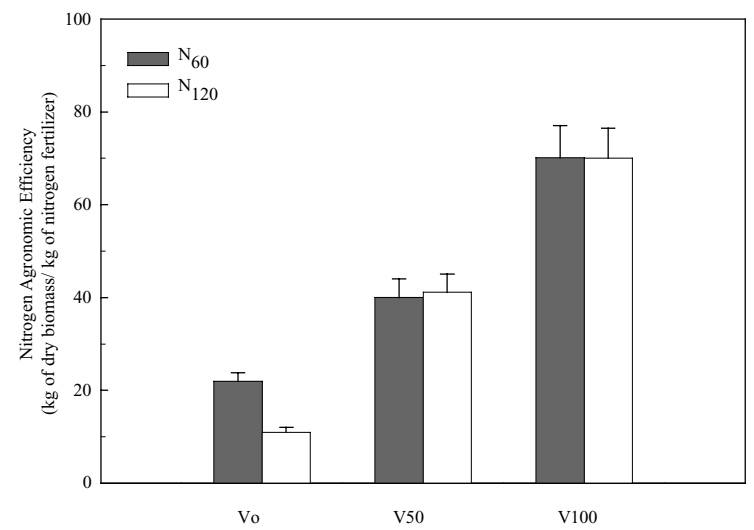

Figure 3. Nitrogen Agronomic Efficiency (N.A.E.) measured during 1997-98 sweet sorghum subject to the irrigated $\left(\mathrm{V}_{0}\right.$, $\left.\mathrm{V}_{50}, \mathrm{~V}_{100}\right)$ and fertilized $\left(\mathrm{N}_{60}, \mathrm{~N}_{120}\right)$ treatments. Vertical bars are standard error of the mean.

1998 no drainage occurred, so that such losses were zero during the growing cycle. In the other year, the nitrate concentration of the waters collected from the lysimeters and from the micro-lysimeters largely varied as a function of the timing of collection, the fertiliser rate and the location.

In our experiment, the role of the crop was significant. The reduction in the nitrate content of the soil solution as the growing cycle advances is certainly to be correlated with the crop nitrogen uptake. Other authors (Barbanti et al., 2006) think that sorghum can be considered a suitable crop in order to drain excessive soil nitrogen reserves, otherwise originating high nutrient loads for the environment to cope with. In fact this crop is able to meet peak $\mathrm{N}$ needs along growth.

As for the nitrogen losses by volatilisation of ammonia, the positive effect of irrigation is explained by considering: i) the $\mathrm{NH}_{4}^{+}$transfer in the soil by mean of water flow favours the sorption of the $\mathrm{NH}_{4}^{+}$on cation exchange capacity, reducing, in this way, the loss of $\mathrm{NH}_{4}^{+}$by volatilisation from the soil surface, ii) the reduced gas diffusion when soil porosity is filled with water. However, in general, also the losses in this form were rather reduced: in the treatments exhibiting higher losses $\left(\mathrm{V}_{0} \mathrm{~N}_{120}\right)$ with an average value of $5.5 \mathrm{Kg} \mathrm{ha}^{-1}$ over the two years, they represented only $4.7 \%$ of the fertiliser rate. The observed data are consistent with other trials on this crop (Barbanti et al., 2006). For sure, the soil conditions positively influenced the low 
measured values of such losses, mainly because of the neutral reaction of the soils of the trial $(\mathrm{pH}=7.1)$ that were favourable to reduce ammonium volatilisation (Giardini, 1989b). Moreover, Sommer et al. (2004) showed lower ammonia emissions from ammonium sulphate than from other fertilizers as urea. In fact ammonium sulphate does not lead to a rise in $\mathrm{pH}$, as does urea, which in turn enhances volatilisation. The association of the adopted fertilizer and of a $\mathrm{pH}$ close to neutrality are, therefore, the main reason of the low emissions observed in our experiment.

As for sweet sorghum nitrogen uptake, the data reported in Table 5 highlight the high nitrogen uptake efficiency and the good capacity of this species to remove nitrogen available in the soil, as reported also by other authors (Gardner et al., 1994).

From the point of view of the environmental impact, these results could be positively interpreted (due to the good capacity of this species to remove the nitrogen compounds present in the soil), but they should be carefully assessed in terms of soil use sustainability. Indeed, it is evident that if the shoot of the crop is completely removed, in order to sustain the soil chemical fertility in balance with the actual crop nutrient uptake, it could be even appropriate to exceed the rates of nitrogen fertilisers applied in this experiment or compensate for nutrient losses in the fertilisation scheduling of the succeeding crops.

As from Figure 1, it is observed that, if we simply consider the uptake by stalks that represent the marketable yield, nitrogen was balanced at a fertiliser rate ranging from $40 \mathrm{Kg} \mathrm{ha}^{-1}$ (in the dry treatments) to $100 \mathrm{Kg} \mathrm{ha}^{-1}$ (in the irrigated treatments). In order to reduce the application rate of fertiliser and concomitantly prevent any critical reduction in the soil nitrogen reserves, one should recommend sweet sorghum crop residual buring (mainly consisting of leaves) that with a $\mathrm{C} / \mathrm{N}$ ratio ranging between 20/1 and 30/1 (Varvel and Peterson, 1991), favourably contributes to the synthesis of stable humic acids in the soil (Giardini, 1997).

The greater amount of $\mathrm{N}$ derived from fertiliser in treatment $\mathrm{N}_{120}$ is explained on the grounds that plants cultivated in the more fertilised treatment, by having a greater amount of readily assimilable nitrogen, preferred nutrient uptake in that form.

Finally, as previously reported, nitrogen losses in the form of ammonia were rather small, especially in the irrigated treatments.

\section{Conclusions}

In conclusion the experimental trial on sweet sorghum was aimed at studying the agronomic and environmental aspects as affected by nitrogen fertiliser and irrigation through monitoring the main nitrogen balance components, lead to the following concluding remarks.

Although an irrigation regime that regularly and fully re-establishes irrigation requirements is the most risky in that it leaches soluble nitrogen compounds (among which nitrates), the high uptake of these fractions by sweet sorghum minimised both nitrate concentrations and total nitrogen losses in drainage waters. However, especially on shallow soils, where water excesses immediately produce drainage, a proper irrigation scheduling is extremely useful to reduce the risk of leaching and for a sound use of water resources.

Total nitrogen losses by volatilisation were proportional to the amount of ammonium sulphate applied; however, both due to the favourable soil conditions (neutral $\mathrm{pH}$ ) and to the positive effect of irrigation - in the case of the irrigated treatments - such losses were very small.

Irrigation proved to be indispensable for the economic sustainability of sweet sorghum in the studied cultivation areas. With respect to the irrigated treatments, the nitrogen fertiliser rate of $120 \mathrm{Kg} \mathrm{ha}^{-1}$, referred to the stalk uptake only, brought the nitrogen balance of the soil quite close to neutrality.

Irrigation improved all the nitrogen use efficiency indexes, highlighting a positive interaction with the fertiliser rate.

\section{References}

Barbanti L., Grandi S., Vecchi A., Venturi G. 2006. Sweet and fibre (Sorghum bicolor (L.) Moench), energy crops in the frame of environmental protection from excessive nitrogen loads. Eur. J. Agronomy, 25:30-39.

Sommer S.G., Schjoerring J.K., Denmead O.T. 2004. Am- 
monia emissions from mineral fertilizers and fertilized crops. Adv. Agron., 82:557-622.

De Franchi A.S., Rivelli A.R., Marano V., Perniola M. 1994. Yield response of sweet sorghum (Sorghum bicolor L. Moench) under different water and fertilizer regimes in environments of Basilicata. In: Proc. Inter. Conf. on "Land and Water Resources in the Mediterranean Region", IAM, Bari, 4-8-sept. 1994, vol. I, 341-356.

Dowdell R.J., Buford J.R., Cress R. 1979. Losses of nitrous oxide dissolved in drainage water from agriculture land. Nature, 278:342-343.

Florenzano G. 1986: Ciclo dell'azoto. In: Fondamenti di microbiologia del terreno. REDA ed., 289-291.

Gardner J.C., Maranville J.W., Paparozzi E.T. 1994. Nitrogen use efficiency among diverse sorghum cultivars. Crop. Sci., 34:728-733.

Giardini L. 1989a. Aspetti agronomici e fisiologici della concimazione azotata in relazione con l'ambiente. Riv. Agron., 23, 1:3-22.

Giardini L., Ceccon P., Giupponi C. 1989b. Rilevazioni sul contenuto in azoto delle acque emunte dagli impianti di drenaggio e stima delle perdite per dilavamento. Riv. Agron., 23, 1:57-63.

Giardini L. 1997. Sostanza organica del terreno e fertilizzanti organici. In: Agronomia Generale, ambientale e aziendale, Patron editore, 379-380.

Marshall V.G., Debell D. 1980. Comparison of four meth- ods of measuring volatilization losses of nitrogen following urea fertilization of forest soilis. Can. J. Soil Sci., 60:549-563.

Mastrorilli M., Katerji N., Rana G., Steduto P. 1995. Sweet sorghum in Mediterranean climate: radiation use and biomass water use efficiencies. Industrial Crops and Products, 3:253-260.

Perniola M., Rivelli A.R., Tarantino E. 1992. Influenza del regime irriguo sulla produzione del sorgo zuccherino (Sorghum vulgare L. var Saccharatum) coltivato in ambiente meridionale. Riv. Agron., 4:517-523.

Perniola M., Rivelli A.R., Tarantino E. 1992. Influenza del regime irriguo sulla produzione del sorgo zuccherino (Sorghum vulgare L. var Saccharatum) coltivato in ambiente meridionale. Riv. Agron., 4:517-523.

Perniola M., Lovelli S., Posca G., Coppola E., Tarantino E. 1999. Effetto del regime idrico e azotato sulle perdite e sulle asportazioni dell'azoto in coltura di sorgo zuccherino. Irrigazione e Drenaggio, 2:52-57.

Sequi P., Vittori Antisari L. 1989. Dinamismo chimico dell'azoto: aspetti agronomici e ambientali. Riv. Agron., 23, 1:30-42.

Smith S.J., Sherpers J.S., Porter L.K. 1990. Assessing and managing agricultural nitrogen losses to the environment. Adv. Soil Sci., 14:1-43.

Varvel G.E., Peterson T.A. 1991. Nitrogen fertilizer recovery by grain sorghum in monocolture and rotation systems. Agron. J., 83:617-622. 